\title{
Review article \\ Ethical considerations on in vitro fertilization technologies in Bangladesh
}

\author{
Islam $S^{I}$, Rusli $B N^{2}$, Hanapi BMN ${ }^{3}$
}

\begin{abstract}
:
This paper aims to address ethical issues related to the assisted reproductive technology method 'in vitro fertilization (IVF)' from the Islamic Shar?'ah. This review reflects that the Islamic ethical viewpoint IVF is rational, comprehensive, and aims at the greatest good of mankind.
\end{abstract}

Key words: In vitro fertilization, assisted reproductive technology, Islam, ethics, Shar?'ah,

\section{Background: Birth of Louise Brown}

After being conceived in a dish, Louise Brown was born in England in 1978. Women like Mrs. Brown, who had been unable to have babies, lined up for the procedure and doctors all over the world moved to duplicate the achievement ${ }^{1}$. Obstetrician Patrick Steptoe and the physiologist Robert Edwards glorified the medical world by in vitro fertilization. Robert Edwards dethroned the fact that gonadotrophic hormones could not make a mammalian ovary release eggs. He could then give barren women a carefully balanced mixture of the hormones, progesterone and estrogen which the ovaries normally release to prepared endometrium to support fertilized egg. He also demonstrated sperm capaciatation may take place outside uterine environment. Edward in one night of 1965 exposed semen on ripe egg in a Petri-dish and in the next morning he observed characteristic features of zygote under microscope. This has latter revolutionized the reproductive medicine. Steptoe's role was based on fiber optics-extremely thin tubes equipped with tiny lights and cameras that can inspect interior body cavities and acquire expertise in harvesting mature follicles(s) from the ovary. In fact, this new technology was the cutting edge factor in the development of infertility assistance Without Steptoe's perfection of this delicate procedure, In Vitro Fertilization (IVF) would still be a dream.

Lesley Brown seemed always in a gloomy mood because after nine years of trying effectively, she failed to conceive. Moreover adoption was not an easy solution at that time. Mrs. Brown's was diagnosed with damaged fallopian tubes possibly resulted from previous ectopic pregnancy. Lesley Brown sought Steptoe's assistance who removed matured egg from her ovaries with laparoscope and exposed to her husband's semen in a petri-dish containing culture medium. Microscopic examination revealed penetration of sperm into egg and the resulting pre-embryo was cultured for two and a half days. Then, the pre-embryo was mixed with a supportive fluid and injected into Lesley's uterus

3. Later on Lesley was declared pregnant. But, it was a normal pregnancy with some minor aliments during the whole period. On the $25^{\text {th }}$ July, 1978, a baby girl was born by caesarian section at Oldham General Hospital. The baby was named Louise Brown and was the first IVF child in the world. Immediately after the birth of the baby, the father expressed his reaction in this way, "For a person who's been told he and his wife can never have children, the pregnancy was 'like a miracle'. I felt 12 feet high"

\section{IVF: Reproductive Physiology}

In vitro is a Latin phrase meaning 'in glass.' So, in embryology, it is used in contrast to in utero or 'in the uterus.' Normally, human fertilization takes place in utero, strictly speaking in the fallopian tubes as already mentioned. IVF then is fertilization that is done artificially outside the woman's body and in a test tube ${ }^{5}$. The popular press often refers to children conceived through the IVF techniques as 'test tube babies'.

\section{Reasons for IVF}

The primary reason for attempting IVF is to bypass damaged or blocks tubes where to produce a

1. Dr. Sharmin Islam, Asst Professor, Northern University Bangladesh

2. Prof. Rusli Bin Nordin, Ex-Deputy Dean, School of Dental Sciences (PPSG), Universiti Sains Malaysia

3. Prof. Hanapi Bin Mohd. Noor, Ex-Director, Islamic Centre (Pusat Islam), Universiti Sains Malaysia

Corresponds to: Dr. Sharmin Islam, Asst Professor, Northern University Bangladesh, House: 54, Road: 4A, Dhanmondi, DHAKA-1209, Bangladesh. E-mail: sharmin320@hotmail.com 
normal pregnancy. If a woman's fallopian tubes are blocked, the egg cannot travel to the uterus. In fact, the purpose of IVF was to replace tubal function by bringing the sperm into contact with the egg in vitro and then transfer the embryo into the uterus. So, one of the most common grounds for attempting IVF is unsuccessful tubal surgery. Tubal surgery may be considered impossible in case of extensive tubal damage where the resulting tubal function would be poor. Tubal ectopic pregnancy is a serious complication of tubal surgery. For this reason, women often prefer to alternative of major surgical reconstructive procedure although they still wish to resolve their problem of tubal infertility ${ }^{6}$ Like Artificial Insemination, IVF separates conception from sexual intercourse ${ }^{7}$ Male infertility also may act as a factor in IVF when the number, movement or structure of the sperms is considered to be abnormal. Successful fertilization has been obtained in the case of men with concentrations of sperms as low as 5 million per milliliter of semen where the normal count range from 20 to 100 million sperm per milliliter of semen. When sperm counts are significantly reduced, however, there is often a high incidence of sperm abnormalities that may impair the effectiveness of IVF. Moreover, there is no chance of pregnancy when the sperm movements are less than 40 percent of those seen normally ${ }^{6}$.

\section{Ethical considerations on test tube baby: Bangladesh perspective}

Bangladesh is a Muslim majority country. People follow the Islamic ethics and laws in all spheres of their life. Around the end of middle age qiyas for medical interventions was inconclusive. It was argued that the analyses were not robust and reliable. However, the issues in the present day are quite different- the IFV, surrogate motherhood, stem cell research and etc. The obstacles in the application of qiyas can yet be achieved by using the theory of purposes of the Law, Maqasid alShar?' $a h$, to derive robust and consistent legal rulings.

The purposes of the law, Maqasid al-Shar?'ah are motivated towards ${ }^{8}$

1. Hifz al Din (Protection of Religion);

2. Hifz al Nafs (Protection of Life);

3. Hifz al Nasl (Protection of Progeny);

4. Hifz al 'Aql (Protection of Mind) and

\section{Hifz al Mal (Protection of Wealth).}

This classification is permanent and describes clearly the paramount and basic necessities of human being. These purposes need protection, preservation and promotion.

The first purpose is protection of din (hifz al din). Protection of din within the domain of medicine refers to maintenance of health. Health here stands both for physical health and mental health. Nobody is capable of doing ibadat properly if he is not sound both physically and mentally. Ibadat in Islam stands on every act done according to the way of Allah (S.W.T).

The second purpose is protection of life (hifz al nafs). In Islamic teachings, both birth and death are controlled by Allah in the absolute sense. But as long as man is alive he deserves a better living. Here lies the role of medicine which should ensure a good life for every human being. Medicine is liable to offer a good quality of life. Preservation and continuation of life is possible when physiological function of the body remains correct. Medicine is also liable to relieve patho-physiological stress by preventive, curative and rehabilitative measures.

Life is sacred and its sanctity is guaranteed by the Holy Qur'an ${ }^{9-15}$. Every life is important as any other life. So destroying the life of one person is equivalent to destroying the life of all humans ${ }^{16}$ Therefore, the first principle of Islamic Medical Ethics would be to preserve the life. Protection of life is the second most important goal of the Shari 'ah, coming second only to the protection of the 'din.' Legal compensation for bodily damage is regarded as replacement of lost earnings and not paying for the value of life. Here the compensation stands for the legal provision to provide sustenance to surviving relatives in case of death. It is also a token for sustenance to persons whose organ was severed and who therefore, can not work to support themselves. The quality of life is multidimensional and it can be improved physically (making it free from disease and offering comfortable environment and basic necessities), mentally (through calmness, absence of neurosis and anxiety and having a purposive life) and spiritually (having correct relation with Allah) ${ }^{17}$.

The third purpose is protection of progeny (hifz al $n a s l$. Protection of progeny bears significance in medicine when medicine aims at caring children so that their good health is ensured. For successful 
birth of children, care for pregnant women, prenatal medicine, paediatrics. Good health is a re-requisite for healthy adulthood, procreation and continuation of human life. As Islam encourages reproduction, it advocates treatment of infertility. Protection of the mind (hifz al 'aql) in relation to medical ethics signifies the necessity of treatment of any physical or mental disease. Recovery from a disease surely brings about mental tranquility.

The fifth purpose is protection of property or wealth. The wealth of any community depends on the productive activities of its healthy citizens. Medicine contributes to wealth generation by prevention of disease, promotion of health and treatment of any disease and their sequels.

Thus, Shari'ah rules and principles are meant to meet the three categories of its objectives i.e. preservation of the absolute essentials, the needs and the complementary values). The three categories consist of (a) absolute necessities (daruriyyat), (b) the complementary (hajjiyat) and (c) beautifications (tahsiniyat)

Those five items belong to the necessary (dar?ri) category. If they are disrupted, the stability and equilibrium in an individual, family and social life are disrupted. Any civilization that wishes to survive must uphold and protects the above mentioned essentials. This classification is permanent and describes clearly the paramount and basic necessities of human being. These purposes need protection, preservation and promotion.

\section{IVF and the Preservation of Progeny (Hifz al Nasl)}

(a) IVF \& the Preservation of Progeny in the Light of the Necessity of Procreation

Islamic Bioethics has a positive attitude towards IVF if it is carried out by a legally married couple. For married couples, procreation is not only encouraged but also a necessity, daruriyyat. As IVF aims at procreation, this technique is most welcome in Islamic Bioethics.

Two stories of infertility in the Qur'an truly reflect the necessity of progeny. One is the story of Ibrahim (AS) and his wife Sara another is that of Zakariya (AS). Regarding the first couple's desire for children it is mentioned in the Qur'an:

"And his wife, standing [nearby], laughed [with happiness]"; whereupon We gave her the glad tiding of [the birth of] Isaac and, after Isaac, of [his son] Jacob." Said she: "Oh, woe is me!' Shall I bear a child, now that I am an old woman and this husband of mine is an old man? Verily, that would be a strange thing indeed!" Answered [the messengers]: "Dost thou deem it strange that God should decree what He wills? ' $\mathrm{O}$ ' The grace of God and His blessings be upon you, O people of this house! Verily, ever to be praised, sublime is He!" ${ }^{18}$.

"[And when he saw that the guests would not eat,] he became apprehensive of them; [but] they said, "Fear not" - and gave him the glad tiding of [the birth of] a son who would be endowed with deep knowledge. Thereupon his wife approached [the guests] with a loud cry, and struck her face [in astonishment] and exclaimed: "A barren old woman [like me]!” They answered: “Thus has thy Sustainer decreed; and, verily, He alone is truly wise, all- knowing!" ${ }^{19}$.

The craving for children of Zakariya's heart is expressed in the Qur'an in the following ways:

"In that self-same place, Zachariah prayed unto his Sustainer, saying: "O my Sustainer! Bestow upon me [too], out of Thy grace, the gift of goodly offspring; for Thou, indeed, hearest all prayer." Thereupon, as he stood praying in the sanctuary, the angels called out unto him: "God sends thee the glad tiding of [the birth of] John, who shall confirm the truth of a word from God, and [shall be] outstanding among men, and utterly chaste, and a prophet from among the righteous." [Zachariah] exclaimed: "O my Sustainer! How can I have a son when old age has already overtaken me, and my wife is barren?" Answered [the angel]: "Thus it is: God does what He wills" The Qur'an also says,

"An Account of the grace which thy Sustainer bestowed upon His servant Zachariah: When he called out to his Sustainer in the secrecy of his heart,' he prayed: "O my Sustainer! Feeble have become my bones, and my head glistens with grey hair. But never yet, O my Lord, has my prayer unto Thee remained unanswered." $"$.

"And [thus did We deliver] Zachariah when he cried out unto his Sustainer: "O my Sustainer! Leave me not childless! But [even if Thou grant me no bodily heir, I know that] Thou wilt remain when all else has ceased to be!" And so We responded unto him, and bestowed upon him the gift of John, having made his wife fit to bear him a child: and, verily, these [three] would vie with one another in doing good works, and would call unto Us in yearning and awe; and they were 
always humble before Us" ${ }^{22}$. Parenthood is very natural instinct of human heart. To quote from the Qur'an,

"Let not, then, their worldly goods or [the happiness which they may derive from] their children excite thy admiration: God but wants to chastise them by these means in this worldly life, and [to cause] their souls to depart while they are [still] denying the truth." ${ }^{23}$.

So, IVF technique fully satisfies the first criteria of the purposes of Shari'ah if it is done between a legally married bond. To quote Dr. Muzammil Siddiqi, former President of the Islamic Society of North America, "based on the principle that the Shari'ah came to protect and preserve the lineage or nasab of the people and thus it is haram to marry a woman during her iddah or to have an intercourse with a woman who is carrying another person's pregnancy, the Muslim jurists have allowed the use of in vitro fertilization only between legally married couples during their marriage. Thus, in vitro fertilization is permissible as long as the semen and ovum are from the couple who are legally married and the fertilization takes place during their marriage, not after divorce or the death of the husband" ${ }^{24}$.

According to the Organization of Islamic Council (OIC) Resolution, there is no objection if one resorts to the following methods, in case of necessity, provided all required precautions are taken: 1. Fertilization in vitro of a woman's ovum by her husband's semen and implantation of the fertilized ovum in the womb of this same woman. ${ }^{2}$. External insemination, by taking the semen of a husband and injecting it in the appropriate place in the womb or uterus of his wife, for in vivo fertilization $^{25}$.

In order to use the husband's frozen sperm, sperms and fertilized ovum are preserved in a sperm bank in frozen state. We shall answer three questions regarding this matter.

Is a man allowed to preserve his sperms in the frozen state?

Are married couples allowed to preserve their fertilized ova for future use?

Is it permissible to sell the sperms of the fertilized ovum?

In answering the first and second question, it can be said that there is nothing wrong with it if serious cautions are taken so that it must not mix with other sperms donated by anybody. And this sperm cannot be used except to impregnate his own wife. This can only be undertaken after free informed consent of the spouse is obtained. The excess preembryos produced can be frozen and stored in liquid nitrogen, a technique called cryopreservation. But cryopreservation should only be allowed in specially designated sperm and pre-embryo banks or ART centers accredited by the relevant health authorities. An exact and full proof system of documentation must be in place to guard against mixing of lineages and commercialism. Confidentiality of information must not be breached and tight security procedures should prevent unauthorized access to records ${ }^{26-27}$. In addition, the Fatwa issued by the European Council for Fatwa and Research states: "It is permissible for the wife to use the sperm of her husband for fertilization unless she is divorced or the husband dies. In case the wife is separated from her husband (i.e. by divorce or death), it's permissible for her then to get rid of the frozen sperm or its remnants"

(b) IVF \& the Preservation of Progeny in the Light of the Necessity of Preservation of Lineage (Hifz al Nasab)

Doing IVF by using donated sperm is surely not allowed in Islam because we have already mentioned that no third party can be involved in a marriage relation. While commenting on this issue, Sheikh Ahmad Kutty, a senior lecturer and Islamic scholar at the Islamic Institute of Toronto, Ontario, Canada, states: "Since it is undoubtedly reprehensible and utterly sinful, no Muslim should ever entertain such a possibility for conceiving a child. A Muslim should accept what Allah (S.W.T) has chosen for him or her. To accept Allah (S.W.T) as a Sovereign Lord and Creator means to believe in His will and ultimate wisdom ${ }^{29}$.

The Qur'an says:

"And God has given you mates of your own kinds' and has given you, through your mates, children and children's children, and has provided for you sustenance out of the good things of life. Will men," then, [continue to] believe in things false and vain, and thus blaspheme against God's blessings?" to be the consorts, meaning husband and wife. So, IVF is Islamically acceptable and commendable following the conditions below:

1. If it solely involves husband and wife and if it 
is performed during the span of their marriage.

2. The union of sperm and ovum must not take place after the husband dies or after divorce.

3. The fusion of sperm and ovum should take place only within the marriage contract.

4. Any donation of alien semen is forbidden.

5. A divorced woman is not permitted to receive the fertilized ovum (embryo) from her ex-husband.

6. A widow is not allowed to take it after the death of her husband.

7. A woman can use the frozen sperm of her husband when both of them are alive.

8. Using frozen sperm before marriage is not permitted.

Family bond is a very significant and strong phenomenon in Islamic bioethics. It tries to protect it in any way. Islamic ethics allows divorce but that is not very much encouraged. If the woman becomes widowed or divorced, then the marriage contract has come to an end. Stored semen of the husband would be alien to her. The woman may face a very adverse situation after the death of the husband. Moreover, when she conceives with the frozen sperm of the husband, questions may arise regarding her character.

\section{IVF and Protection of Life (Hifz al Nafs)}

In IVF procedure, some sperms, ova and zygotes may remain surplus and unused. Ethical issues related to spare embryos involve the following questions:

1. The most important ethical issue in this process seems the question: should an embryo which is formed after fertilization in a test tube and is not yet in the womb of the mother be considered a human being with all the rights of a human being?

2. Is it correct to produce embryos only for research purpose?

3. Is it right to destroy the spare embryos?

4. Can these embryos be used for research purpose? etc.

Regarding the first question, we should have a clear understanding of the concept of soul or ' $r u h$ ' based on the Qur'an. Allah, the Almighty speaks about this idea in different verses and several meanings were given by commentators. However, Yousuf Ali and Mohammad Asad considered 'ruh' 'divine inspiration'. According to the Qur'an, the stage at which the soul breathed into the forming body within the womb, takes place after it has passed through the stages of Nutfah, 'Alakah, Mudgah, bone formation and flesh formation that covers the bone ${ }^{31}$

The Qur'an says:

"Now, Indeed, We create man out of the essence of clay, and then We cause him to remain as a drop of sperm in [the wombs] firm keeping."

These verses indicate seven stages of fetal development $^{31}$.

1. The First stage: This point to the creation of Adam from clay--- that is soil and water. To put it in another way: sperm and ovum come from human bodies which are built from nutrients that originate from clay. The Qur'an says, "who makes most excellent everything that $\mathrm{He}$ creates. Thus, He begins the creation of man out of clay; then $\mathrm{He}$ causes him to be begotten out of the essence of a humble fluid." ${ }^{33}$.

2. The Second stage: The outcome of spermovum unification is the formation of 'zygote'. This is explained scientifically by saying that half chromosomes are derived from each parent and then added together to form the fertilized ovum.

3. The Third stage: This is the stage of the hanging clot which forms around the $7^{\text {th }}$ day from fertilization. The picture of this early fetus looks like an object hanging to the endometrium by fine villi which will develop further in stages. Many scholars identify this stage as the first and very early form of life in human development.

4. The Fourth stage: The fetus in this stage of development looks like a partially chewed piece of meat( The Arabic word 'mudgahah' is used to refer to this flesh mass or mass of somites). This stage begins at the end of the $3^{\text {rd }}$ week or the beginning of the $4^{\text {th }}$ week.

5. The Fifth stage: This is the stage of bone development. Embryo is nothing but a boneless lump. Its cartilage tissue is transformed into bones in due time as described in the Qur'an which is followed by their being clothed by muscular flesh (The Arabic word 'lahm' stands for the muscular flesh). The Qur'an says,

"and then We create out of the drop of sperm a germ-cell, and then We create out of the germ-cell an embryonic lump, and then We create within the embryonic lump bones, and then We clothe the 
bones with flesh - and then We bring [all] this into being as a new creation: hallowed, therefore, is God, the best of artisans!" ${ }^{34}$.

6. The Sixth stage: Several days after bone development, early muscles start around the vertebrae at the $6^{\text {th }}$ week and muscles around the extremities at the $7^{\text {th }}$ week.

7. The Seventh stage: This is the stage in which a new creation is formed. According to some contemporary scholars, fetuses vary slightly in acquiring ' $r u h$ '. The least time is 40 days and the maximum is $\mathbf{4 5}$ days. Some still hold the view that ' $r u h$ ' starts after 120 days of fertilization ${ }^{35}$.

So, our decision is easy to derive from the above explained process of human development on the basis of the Qur'an that there is nothing wrong with the idea that embryos created in the test tube but not implanted in the womb has no soul or life. Thus, it is a lifeless creature. If it is not placed in the womb it will not survive. Even a fertilized ovum outside the womb or inside it without implantation cannot end up as a human being ${ }^{31}$.

To address the second question, we can say that it is true that compared to stem cells derived from early embryos, the potential of tissues from the umbilicus, fetuses (mature embryos) and adult tissues are more limited. Nevertheless, embryos must not be created for the purpose of research motive only since to create a life in order to end it rivals the actions that belong only to God. Experimentation in human pre-embryos would be allowed only if it is for the good of the individual pre-embryos or if the mother's life is in danger following the research the pre-embryos can be transferred only to the owner of the ova, and only during validity of a marriage contract ${ }^{36}$. Therefore, we should prohibit making embryos for research concern.

It should remember that Islam is a religion which should be measured in its totality, not partially. Man was created to live in harmony with nature. The social aspect of Islamic ethics is very strong and dynamic as well. It always forbids any kind of social disorder and disharmony. Nowadays, it is assumed that isolating the stem cells of embryos for research purposes because it ultimately benefits humanity and society as a whole without violating the right of anybody. The progressive and brilliant stance of Islamic ethics imposes no restriction on scientific intervention rather reinforces it.
Anything that disrupts life and brings about chaos in the natural order is prohibited in Islamic ethics. So creating human embryos for research purposes only does not satisfy our consensus.

To address the third question we should say, in order to avoid risk, in most case of $\mathrm{AIH}$, three ova are removed from the wife's ovaries. Then, all of them are fertilized by the husband's sperms. But only one is used for re-implantation in to the wife's womb. In case of failure of the first attempt, other fertilized ova are used. Significant moral questions are raised by ethicists about the extra and unwanted fertilized ovum.

a. What should be done with the surplus fertilized ovum?

b. Should it be used or destroyed?

Islamic ethics finds no problem in destroying the surplus fertilized ovum. Some may doubt whether it is a form of abortion or not. Actually, it does not involve abortion because abortion only takes place after the implantation of the fertilized ovum in the womb and abortion takes place in a female's body not in the laboratory dish or test-tube. Regarding the use of surplus of fertilized ova, Organization of Islamic Council (OIC) Resolution is that firstly only the number of ova required each time for insemination must be fertilized to avoid the existence of surplus fertilized ova. If an extra fertilized ova exists in any way, it shall be left without medical care until the life of it ends naturally ${ }^{25}$.

To address the fourth question, we can say that the surplus fertilized embryos might have a good potential for research purpose for human benefit. But the cryopreserved pre-embryos may be used for research purposes with the free informed consent of the couple and should be limited to therapeutic research. The treated pre-embryos may be transferred only to the uterus of the wife, who is the owner of the ova and only during the marriage span. Research aimed at changing the inherited characteristics of pre-embryos including sex selection is not allowed. Non-therapeutic research is permissible on excess pre-embryos to improve the treatment of infertility, contraception, reproductive medicine, genetics, cancer, and embryology. But free informed consent of the couple is required ${ }^{37}$ Among the fundamental principles of Ijtih?d is maslahah mursalah (consideration of public interest). In dealing with the issue of spare embryo research, it is important to keep all of these principles and the basic legal framework in mind. 
When a Muslim scholar reaches a conclusion about stem cell research, he should evaluate such conclusion in light of public interest. If the well-being of the community is being threatened for some reason, then the scholars must consider that fact, which is subsumed under principle (3) above, in reaching their final decisions. This is one reason why laws change with the change of time and place. Thousands of embryos that would otherwise be discarded in fertility clinics could potentially be used for research. This is not contradictory to the spirit of Islamic principles. Even it is a societal obligation to perform research on these extra embryos instead of discarding them because people would surely be benefited from such research. But there should be strict guidelines and proper procedures to ensure there is no potential abuse.

\section{IVF and Protection of the Mind (Hifz al 'Aql)}

IVF must fulfill the requirement of mental satisfaction. It is true that although this technique seems very simple, in fact it is not so. The couple has to come under medical treatment and different kinds of procedures month after month and even year after year. The woman has to have fertility drug for stimulation of the ovum. But still, some couples prefer trial and error method rather than becoming childless. So, if it leads to their mental satisfaction, then, why should they not try for it? If any couple becomes tired and exhausted due to failure of several attempts, then what would be their consolation? They can remember the verse of the Qur'an,

"God's alone is the dominion over the heavens and the earth. He creates whatever $\mathrm{He}$ wills: $\mathrm{He}$ bestows the gift of female offspring on whomever
He wills, and the gift of male offspring on whomever $\mathrm{He}$ wills; or $\mathrm{He}$ gives both male and female [to whomever $\mathrm{He}$ wills], and causes to be barren whomever He wills: for, verily, $\mathrm{He}$ is allknowing, infinite in His power" ${ }^{38}$.

\section{IVF and Protection of Wealth (Hifz al Mal)}

Islamic legal principles not only try to ensure peoples' faith, progeny, life, and mind but also are apt to preserve the wealth of mankind so that they would not become helpless in adverse situations. IVF is really an expensive procedure. If a couple is in such a situation that attempt of IVF will make them insolvent in future, and then they should refrain from. An Islamic society should give priority to physical health and poverty than IVF.

\section{IVF and protection of Faith (Hifz al Din )}

IVF if performed within marriage bond and marriage span does not have any conflict with the protection of faith (Hifz al Din). Rather this technique, if it is successful in removing the barrenness of a couple may help them undertaking all the responsibilities of ibadat.

\section{Conclusions}

The above study reveals the fact that while Western secular bioethics is arguing to validate the use of donor sperm and egg in IVF technique, Islamic bioethics thinks about the problem of lineage. The approach of Islamic bioethics seems deeper and thought-provoking for the welfare of the society as a whole because it strictly keeps the identity of the child and inheritance law intact. A very coherent and logical form of social justice is reflected here. Islamic bioethical ideas about IVF is dynamic and proves that long term good is beneficial than temporary satisfaction of desires.

\section{References:}

1. Pence, GE. Classic Cases in Medical Ethics. 2nd Ed. New York: Mc Graw-Hill 1995.

2. Musa Mohd Nordin. Human genetic and reproductive technologies - an international medicolegal-religious impasse? Bangladesh Journal of Medical Science 2010; 10(1): 01-10. DOI: 10.3329/bjms.v10i1.7311http://dx.doi.org/10.33 29/bjms.v10i1.7311

3. Musa Mohd Nordin. An Islamic Perspective of Assisted Reproductive Technologies. Bangladesh
Journal of Medical Science 2012; 11(4): 252257.http://dx.doi.org/10.3329/bjms.v11i4.12594

4. Brown, J and Brown, L. Our Miracle Called Louise. London: Paddington 1979.

5. Munson, R. Reproductive Control: In Vitro Fertilization, Artificial Insemination and Surrogate Pregnancy. In: R, Munson,(ed). Intervention and Reflection: Basic Issues in Medical Ethics, 5th edition. Stamford: Wadsworth 1996:489-551.

6. Leeton, JF, Trounson, AO and Wood, C. IVF 
and ET: What It is and How it Works. In: W.A.W Walters, P. Singer,(ed).Test Tube Babies. Melbourne: Oxford University Press 1984:2-10.

7. Annonymous (a) Reproductive technologies. In: SG Post (ed). Bioethics for students: How do we know what's right? Issues in Medicine, Animal Rights and the Environment 1999;1.

8. Kasule, OH. Medical Jurisprudence Between Originality and Modernity. Proceedings of the 5th Scientific Meeting of the Islamic Medical Association of Malaysia, Penang, May 28-29, 2004.PMid: 15490717

9. Glorious Qur'an, Chapter 2, Verse 84-85.

10. Glorious Qur'an, Chapter 4, Verse 29.

11. Glorious Qur'an, Chapter 5, Verse 32.

12. Glorious Qur'an, Chapter 6, Verse 151.

13. Glorious Qur'an, Chapter 17, Verse 33.

14. Glorious Qur'an, Chapter 18, Verse 74.

15. Glorious Qur'an, Chapter 25, Verse 68.

16. Glorious Qur'an, Chapter 25, Verse 32.

17. Kasule, $\mathrm{OH}$. A Critique of the Biomedical Model from an Islamic Perspective. In: H.E. Fadel,(ed). FIMA Year Book 2002. Islamabad: Federation of Islamic Medical Associations in collaboration with Medico Islamic Research Council (MIRC) and Islamic International Medical College 2003: 95-108.

18. Glorious Qur'an, Chapter 11, Verse 71-73.

19. Glorious Qur'an, Chapter 51, Verse 28-30.

20. Glorious Qur'an, Chapter 3, Verse 38-40.

21. Glorious Qur'an, Chapter 19, Verse 2-4.

22. Glorious Qur'an, Chapter 21, Verse 89-90.

23. Glorious Qur'an, Chapter 9, Verse 55.

24. Anonymous (b) (2005) In Vitro Fertilization: Islamic View [Online]. [Accessed 15th June 2005]. Available from World Wide Web: http://islamonline.net/fatwa/english/FatwaDispla y.asp?hFatwaID $=100160$.

25. Anonymous (c) (2006) OIC Resolution [Online]. [Accessed 15th October 2006]. Available from World Wide Web: www.islamibankbd.com/page/oicres.htm.

26. Mishal, AA. (a) Cloning and Advances in Molecular Biotechnology: Islamic Shariah Guidelines. In: HE. Fadel,(ed). FIMA Year Book
2002. Islamabad: Federation of Islamic Medical Associations in collaboration with Medico Islamic Research Council (MIRC) Islamic international Medical College 2002: 33-47.

27. Serour, GI. (2006) Bioethics in Infertility Management in the Muslim World. [Online] [Accessed 10th July 2006]. Available from World Wide Web: www.islamicworld.net/sister/h12htm.

28. Anonymous (d) (2005) Using a Husband's Frozen Sperms [Online]. [Accessed 15th June 2005]. Available from World Wide Web: http://www.islamonline.net/fatwa/english/Fatwa Display.asp?hFatwaID $=71039$.

29. Annonymous (e)(2005) IVF Using Donated Sperm [Online]. [Accessed 15th June 2005]. Available from World Wide Web: http://islamonline.net/fatwa/english/FatwaDisplay.asp?h F atwaID $=109678$.

30. Glorious Qur'an, Chapter 16 Verse 72. 31. Mishal AA. (b) Human Life Before Birth: the Contemporary Issues. In: H. E. Fadel, (ed). FIMA Year Book 2002. Islamabad: Federation of Islamic Medical Associations in collaboration with Medico Islamic Research Council (MIRC) and Islamic international Medical College 2002: 1-14. 32. Glorious Qur'an, Chapter 23 Verse 12-13. 33. Glorious Qur'an, Chapter 32 Verse 7-8. 34. Glorious Qur'an, Chapter 42 Verse 4950. 35. Ahmad, ID (a) (2005) Federal Funding for Stem Cell Research [Online]. [Accessed 15th June 2005]. Available from World Wide Web: http://www.islamonline.net/english/Views/2001/ 08/article6.htm.

36. Schenker, JG. (2005) International Regulation of Human Embryo Research, FIGO Statements and World Experience [Online]. [Accessed 15th June 2005]. Available from World Wide Web: http://www.humrep. oupjournals. org/cgi/reprint/13/8/2047.pdf.

37. Serour GI. (2005). Reproductive Choice: A Muslim perspective [online]. [Accessed 15th June 2005]. http://www.hsph.harvard. edu/organizations/grhf/SAsia/suchana/1130/rh393.html 38. Glorious Qur'an, Chapter 42 Verse 49-50. 